H. van der Westhuizen Department Historical and Constructive Theology, UFS. Email: hvdw@ufs.ac.za

DOI: http://dx.doi. org/10.18820/23099089/ actat.v38i1.12 ISSN 1015-8758 (Print) ISSN 2309-9089 (Online) Acta Theologica 2018 38(1):163-166

(C) UV/UFS

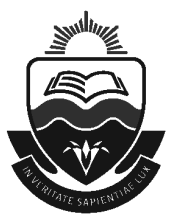

REVIEW

\section{REFORMING MEMORY: ESSAYS ON SOUTH AFRICAN CHURCH AND THEOLOGICAL HISTORY}

VOSLOO, R. (Stellenbosch: African Sun Media, 2017). 287 pp. ISBN: 978-1-9283-14-36-3

In Reforming memory, Robert Vosloo reaffirms the importance of memory in a time of forgetting, of wilful forgetfulness and ways of remembering furthering various forms of injustice.

For him, it is important to reflect on the question of how we remember - particularly also in South Africa, today. The title, therefore, has an ambiguous meaning. It refers, on the one hand, to the reforming ability of memory and, on the other, to memory that is itself in need of reformation. In fact, "we often wound others through the ways in which we ... construct the past" (p. ix).

In his introduction, Vosloo recollects that the book is a collection of essays all written after his appointment as lecturer at Stellenbosch University. It is in these lectures that he realized the importance of a responsible historical hermeneutic. For him, it was clear that "even though there was a common history (amongst those he lectured to), this shared history was a deeply divided and ambivalent history" (p. ix).

The first part of the book therefore seeks a responsible historical hermeneutic. His assumption is that whatever we regard as access to the past are by no means "self-evident and do[es] not speak for themselves" (p. ix). They are "in need of interpretation, and our interpretations and appropriations are 
determined by the place from where we read and write, hear and speak" (p. ix). This section therefore deals with the themes in the title of Paul Ricoeur's Memory, history and forgetting (2004) - in reverse order.

The first essay On forgetting asks "whether we can speak - also with theological integrity - of an art or even a duty of forgetting" (p. 5). He argues that the art of forgetting "can only find its place on the other side of a critique of forgetting and in close proximity to memory" (p. 13). For him, there is no strict symmetry between the art of memory and the art of forgetting. $\mathrm{He}$ therefore asks not only for a way of remembering that enables justice to be done to the past, but also for a way of remembering that enables a just future. He warns that 'the language of 'forgetting' cannot be used as an alibi to forget or erase the past, since the past remains in the present; it can only be used and claimed with the healing motive of lifting the weight or the burden of the past" (p. 14). Already in the first essay, he thus begins to develop a historical hermeneutic responsible, because it does not want to exclude.

In his essay On history, Vosloo is drawn not only to Ricoeur's "sensitivity to what one can describe as the vulnerability and instability inherent in attempts to represent the past" (p. 16), but also to his concern with "the faithful or truthful representation of the past" (p. 16). He is critical of "claims regarding historical objectivity that disregard the role of the subject" (p. 22). Rather, a historical hermeneutic is to be "a vulnerable as well as a realistic hermeneutic" (p. 24), a hermeneutic "sensitive to the way in which representations of the past have led to exclusion" (p. 24).

His essay On remembering therefore "seeks some conceptual clarity on the intricate interrelation between memory and history", between remembrance and historiography. He critically asks whose memories of the past are remembered, and if those recalling the memories of the past at present deal with those memories through history, "through a responsible historical epistemology and hermeneutic" (p. 36). He asks if those remembering are themselves remembering with justice in mind: "With whom - and in which communities and as part of what tradition are we grappling with our interwoven and often contested constructions of the past?" (p. 36). It is in this tension between memory and history, he argues, that we are "continually challenged to narrate the historical past other-wise" (p. 36).

This is further developed in his essay On the archive. For Vosloo, the archive "can be used as a broader metaphor or concept that relates to the body of knowledge produced about the past". In light of Jacques Derrida's Archive fever (1996), he "aims to interrupt discourse on the archive by 
exposing the ways in which the concept of the archive is inescapably linked to archontic power" (p. 40). In fact, archives are "monuments to the way in which power is reconfigured" (p. 40). Archives precisely do not merely include, but "testify to a narrative of exclusion" (p. 40). By archiving other-wise, he therefore aims at "challenging the hegemony of certain constructions of the past" (p. 45).

That a responsible historical hermeneutic thus challenges the mentioned forgetting, wilful forgetfulness, and ways of remembering that furthers injustice, becomes particularly clear in the second part of the book, where he revisits parts of the history of the Dutch Reformed Church in the previous century. This is important not only for the reforming of those memories, but also for these reforming memories to continually reform. It is interesting to note that the essays in this section end with contemporary challenges.

In On division, for example, he asks if the concern for internal unity within the Dutch Reformed Church is still what drives their theology and if the church can find the needed theological resources "to challenge reductive and narrow conceptualizations" of, for example, unity (p. 125). In On Scripture, he asks "how our reading of the Bible is determined by beleaguered, fixed, isolationist and polarised identity constructions" (p. 138). In an essay On poverty, he reiterates that the challenges remain for the church, including the Dutch Reformed Church, to address problems in contemporary South Africa "in an inclusive way" (p. 104). In On urbanization, he reaffirms the challenges posed by what many perceive as inhospitable spaces or places (p. 114). What, he asks, if our reading of the Bible is marked by a hermeneutic of hospitality?

What he means by a hermeneutic of hospitality becomes clearer in the third part of the book, where he revisits engaging Reformed theologians (e.g., John Calvin, Beyers Naudé, Dirkie Smit, and John de Gruchy).

In the essays On Calvin, for example, he finds an unexpectedly rich and as yet untapped resource for a theology of hospitality. In times characterised by "migration, displacement and xenophobia", he argues that Calvin, with all his limitations, "may provide surprising insights that can aid in the reclaiming of a theology of hospitality" (p. 188). In fact, Calvin has "continuing significance to sustain a theology of hospitality towards contemporary 'widows, orphans, and strangers'” (p. 188).

This point is also clear in the fourth part of the book, where he revisits reforming practices (e.g., Lord's Supper, Heidelberg Catechism, and the Belhar Confession). 
In On the Lord's Supper, for example, he writes:

In situations where human beings seek for ways to affirm their identity and ensure their survival, which are playing out with increasing frequency in various forms in our ... world today, the temptation looms large to compromise the grace of God's embrace in the name of protecting identity, establishing security or ensuring survival. Amidst these temptations ... the church (is reminded) to embody visibly God's haunting hospitality (p. 253).

Reforming memory is published as part of the Beyers Naudé Centre Series on Public Theology, and this indeed is church and theological history as public theology. In these essays, Vosloo elicits not only a passion for the past, but also a passion for justice and for a just future - a justice characterised by his complex conceptualization of hospitality. For him, remembering is precisely not to be separated "from taking responsibility for tomorrow and the expectation of the future to come" (p. 48). 